\title{
Simulating larval Antarctic krill growth and condition factor during fall and winter in response to environmental variability
}

\author{
Alexander T. Lowe ${ }^{1,4, *}$, Robin M. $\operatorname{Ross}^{1}{ }^{1}$ Langdon B. Quetin ${ }^{1}$, Maria Vernet ${ }^{2}$, \\ Christian H. Fritsen ${ }^{3}$

\begin{abstract}
${ }^{1}$ Marine Science Institute, University of California Santa Barbara, Santa Barbara, California 93106-6150, USA
${ }^{2}$ Integrative Oceanography Division, Scripps Institution of Oceanography, La Jolla, California 92093-0218, USA ${ }^{3}$ Division of Earth and Ecosystem Sciences, Desert Research Institute, Reno, Nevada 89512, USA
\end{abstract} \\ ${ }^{4}$ Present address: Friday Harbor Laboratories, University of Washington, Friday Harbor, Washington 98250, USA
}

\begin{abstract}
The first winter in the life cycle of Antarctic krill Euphausia superba is a critical period in which larval survival and recruitment to the adult population are highly sensitive to environmental conditions, yet little is known about larval physiological dynamics during this period. An individual-based model was developed to investigate patterns of larval krill growth and condition factor in response to environmental variability during fall and winter, west of the Antarctic Peninsula. Field and experimental observations from Southern Ocean Global Ocean Ecosystems Dynamics cruises in 2001 and 2002 and the Palmer Long-Term Ecological Research program were used to parameterize the model. Growth was modeled by partitioning total body carbon between length and condition factor. Total body carbon was simulated with empirical temperature-dependent rates of ingestion of phytoplankton and respiration, and ingestion of algae grown on a surface to simulate sea ice algae. Light-driven diel vertical migration modulated ingestion of phytoplankton and sea ice algae as a function of latitude, season and sea ice cover. Simulations highlighted 3 environmental processes that controlled food availability, and consequently, physiological condition of krill: the fall phytoplankton decline, sea ice advance and development of sea ice microbial communities, and the late winter increase in sea ice microbial community biomass. Fall phytoplankton dynamics were identified as a major driver of the physiological condition of larval krill throughout this critical period. The model presents a mechanism that links larval krill survival and recruitment to fall and winter variability in phytoplankton and sea ice dynamics along the western Antarctic Peninsula.
\end{abstract}

KEY WORDS: Euphausia superba · Larval Antarctic krill · Condition factor · Growth · Individualbased model $\cdot$ Fall and winter $\cdot$ Critical period

\section{INTRODUCTION}

The Antarctic krill Euphausia superba is an abundant zooplankton species in the Southern Ocean and an important link in the transfer of carbon from primary producers to top predators (Laws 1985, Everson 2000). Regional krill populations exhibit large interannual fluctuations driven by recruitment success
(Siegel \& Loeb 1995, Quetin \& Ross 2003, Siegel 2005) as a function of adult reproductive output and the survival of larval krill to adulthood (Ross \& Quetin 1991). Unlike adult krill that can survive more than 200 d without feeding (Ikeda \& Dixon 1982) larval krill entering the winter generally have not accumulated sufficient energy reserves to survive long periods of starvation before the seasonal decline in 
phytoplankton abundance (Meyer \& Oettl 2005). Young-of-the-year krill must feed more or less continuously to meet respiratory demands. The first winter, when survival is dependent on larval access to food (Ross \& Quetin 1991), is thus a critical period in the life cycle of Antarctic krill.

During this period primary production in the water column is limited by decreasing light availability. The formation of seasonal sea ice further decreases light penetration. This results in very low concentrations in the water column of phytoplankton upon which larval krill graze. However, the developing sea ice scavenges phytoplankton and other particles from the water column, so that algae, microzooplankton and nutrients are concentrated in the newly formed sea ice (Garrison et al. 1983, 1989). The concentration of algae and other organisms that comprise the sea ice microbial communities (SIMCOs) represents an important seasonal food source for larval krill (Daly \& Macaulay 1991, Schmidt et al. 2006). While larval krill feed primarily on autotrophs in the water column and sea ice (Ross et al. 2000, Meyer et al. 2009), concentrations of heterotrophs such as tintinnids, dinoflagellates and copepods may contribute significantly to the diet of larvae in winter (Meyer et al. 2002, Schmidt et al. 2006).

The availability of biota that larval krill rely on to meet energetic demands during winter is controlled by sea ice dynamics (Ackley \& Sullivan 1994). Correlative studies of Antarctic krill recruitment and seasonal sea ice dynamics indicate that timing of formation, areal extent and duration of sea ice are important variables that determine recruitment success (Siegel \& Loeb 1995, Quetin \& Ross 2003). The timing of sea ice advance has received much attention based on the role of SIMCOS as an important food source for larval krill (Daly 1990, Quetin \& Ross 2003, Quetin et al. 2007). When sea ice develops early, it has the potential to scavenge more phytoplankton from the water column and provide a stable habitat with enough light to promote in situ production and development of SIMCOs (Fritsen et al. 2008). When sea ice develops late in winter, the cumulative effect of reduced phytoplankton concentrations available for scavenging and lower light yields decreases in situ production and provides less food for krill. Many studies have investigated the interaction between krill and sea ice on behavioral (Stretch et al. 1988, Daly 1990, Daly \& Macaulay 1991), physiological (Frazer et al. 2002, Meyer et al. 2002, 2009, Oakes 2008) and population scales (Siegel \& Loeb 1995, Quetin \& Ross 2003, Wiedenmann et al. 2009), yet we continue to lack a comprehensive understanding of the mechanisms underlying the relationship between sea ice variability and larval krill dynamics. Previous modeling efforts greatly advanced our understanding of potential over-wintering strategies and requirements for Antarctic krill (Hofmann \& Lascara 2000, Fach et al. 2008); however, those authors recognized the limitations of those models without empirical information regarding winter physiology and behavior, especially for larval krill.

In the present study, an individual-based model (IBM) was developed for larval Antarctic krill with empirical measurements of temperature-dependent ingestion (Oakes 2008, L. B. Quetin, R. M. Ross, A. T. Lowe, S. A. Oakes, M. O. Amsler unpubl. data) and respiration rates (re-analysis of Frazer et al. 2002), experimental quantification of ingestion by grazing on SIMCOs (Oakes 2008) and observations of seasonal, light-driven, diel vertical migration (DVM) behavior. The carbon-based IBM was used to investigate the dynamics of larval krill physiological condition in response to environmental variability in fall and winter in 2 regions along the western Antarctic Peninsula (wAP). Specifically, we tested the hypothesis that early sea ice advance and concomitant development of SIMCOs is a critical process for maintaining physiological condition and survival of larvae through the winter. In this study, physiological condition is described by growth rate and condition factor $(C F)$, a measure of organic matter per unit volume, both of which are attributes of the nutritional history of the individual (Ross \& Quetin 1991). The larval krill IBM is one component of a modeling effort aimed at examining linkages among phytoplankton, ice, ice algae and krill (PIIAK Project) in relation to temporal and spatial variability along the wAP. The larval krill dynamics model was coupled to models of fall and winter phytoplankton (Vernet et al. 2012, this volume) and sea ice algal dynamics (Fritsen et al. 1998). The study synthesized research from Southern Ocean Global Ocean Ecosystem Dynamics (SO GLOBEC) cruises in 2001 and 2002, the Palmer Long-Term Ecological Research (LTER) program and studies conducted at Palmer Station (US Antarctic Program).

\section{MATERIALS AND METHODS}

Functional relationships to determine the carbon budget of a larval krill were parameterized with experiments conducted at Palmer Station, Antarctica, and 2 regions along the wAP. The northern region, 
Palmer Basin $\left(64^{\circ} 42^{\prime} \mathrm{S}, 65^{\circ} 02^{\prime} \mathrm{W}\right)$, lies within the Palmer LTER study area. The southern region, Marguerite Bay $\left(67^{\circ} 46^{\prime} \mathrm{S}, 69^{\circ} 57^{\prime} \mathrm{W}\right)$, lies south of Adelaide Island and southwest of Rothera Base (British Antarctic Survey). Marguerite Bay, with the adjacent shelf area, was the site of SO GLOBEC research cruises in fall and winter of 2001 and 2002. Palmer Basin and Marguerite Bay are regions with high primary productivity (Marrari et al. 2008, Vernet et al. 2012) and historically high larval abundances (Meyer et al. 2003, Quetin \& Ross 2003, Pakhomov et al. 2004).

The carbon budget (total body carbon, $C_{\mathrm{b}}$ ) of an individual larval krill is defined as:

$$
C_{\mathrm{b}}=I_{\mathrm{WC}}+I_{\mathrm{SI}}-R-E g
$$

where $I_{\mathrm{WC}}$ and $I_{\mathrm{SI}}$ are the ingestion rates of phytoplankton in the water column and autotrophs in the sea ice (SIMCOs), respectively. Carbon losses from the individual result from respiration, $R$, and egestion of unassimilated material, Eg. Variables used in the model are listed in Table 1. The larval krill IBM was coupled with output from the phytoplankton and

Table 1. Definition and units of model variables used to simulate larval Antarctic krill Euphausia superba growth and condition factor

\begin{tabular}{|c|c|c|}
\hline Variable & Description & Units \\
\hline$C_{\mathrm{b}}$ & Total body carbon & $\mu g \mathrm{C}$ \\
\hline$I_{\mathrm{WC}}$ & $\begin{array}{l}\text { Rate of ingestion of water } \\
\text { column phytoplankton }\end{array}$ & $\mu \mathrm{g} \mathrm{C} \mathrm{mg}{ }^{-1} \mathrm{~h}^{-1}$ \\
\hline$I_{\mathrm{SI}}$ & Rate of ingestion of SIMCOs & $\mu g \mathrm{Cmg}^{-1} \mathrm{~h}^{-1}$ \\
\hline$R$ & Respiration rate & $\mu g \mathrm{Cmg}^{-1} \mathrm{~h}^{-1}$ \\
\hline$E g$ & $\begin{array}{l}\text { Rate of egestion of } \\
\text { unassimilated carbon }\end{array}$ & $\mu g \mathrm{Cmg}^{-1} \mathrm{~h}^{-1}$ \\
\hline$W$ & Wet mass of larval krill & $\mathrm{mg}$ \\
\hline$L$ & Total body length & $\mathrm{mm}$ \\
\hline$C F$ & Condition factor of larval krill & $\mu \mathrm{g} \mathrm{C} \mathrm{mm} m^{-3}$ \\
\hline$A E$ & Assimilation efficiency & $\%$ \\
\hline$f$ & Feeding time budget, $t$ or $(1-t)$ & $\mathrm{h}$ \\
\hline$D F$ & Hour of daylength per $24 \mathrm{~h}$ perioc & $\mathrm{h}$ \\
\hline$t$ & $\begin{array}{l}\text { Adjusted fraction of } D F \text { spent } \\
\text { feeding }\end{array}$ & $\begin{array}{l}\text { Dimension- } \\
\text { less }\end{array}$ \\
\hline$\alpha$ & Carbon partitioning constant & $\%$ \\
\hline C:chl & $\begin{array}{l}\text { Ratio of autotroph carbon } \\
\text { to chl a concentration }\end{array}$ & $\begin{array}{l}\text { Dimension- } \\
\text { less }\end{array}$ \\
\hline$T$ & Water temperature & ${ }^{\circ} \mathrm{C}$ \\
\hline $\mathrm{Chl}_{\mathrm{SML}}$ & $\begin{array}{l}\text { Surface mixed layer chl a } \\
\text { concentration }\end{array}$ & $\mathrm{mg} \operatorname{chl~} a \mathrm{~m}^{-3}$ \\
\hline $\mathrm{Chl}_{\mathrm{SI}}$ & Sea ice chl a concentration & $\mathrm{mg} \operatorname{chl} a \mathrm{~m}^{-3}$ \\
\hline$D$ & Day of year & \\
\hline
\end{tabular}

SIMCO dynamics models with STELLA, a modeling software released by the software company, isee systems.

\section{Carbon gains}

Ingestion ( $\left.\mu \mathrm{g} \mathrm{C} \mathrm{krill}^{-1} \mathrm{~h}^{-1}\right)$ is a function of chl a concentration, water temperature and wet mass of the individual. The equation for water column ingestion was derived from multiple ingestion rate experiments conducted at $-1.5^{\circ} \mathrm{C}$ and $+1.5^{\circ} \mathrm{C}$ (austral fall 1988, R. M. Ross, A. T. Lowe, S. A. Oakes, M. O. Amsler unpubl. data; austral spring 2002, L. B. Quetin \& R. M. Ross). Ingestion rates were measured for cultured phytoplankton fed furcilia II to VI in the laboratory and calculated by following the methods of Marin et al. (1986) and described in Lowe (2010). The functional response to chl a concentration was described by Ivlev equations for each temperature. Two physiological functions, respiration rate and developmental time of larval krill, exhibited an exponential response to temperature (Ross et al. 1988, Quetin \& Ross 1989, Frazer et al. 2002). Ingestion rates were also assumed to exhibit an exponential response to temperature and equations describing the exponential response were derived for the Ivlev parameters (maximum ingestion rate, $a$, and chl a concentration effect, $r$ ). The functional feeding response is:

$$
\begin{aligned}
& I_{\mathrm{SML}}=a\left(1-\mathrm{e}^{-r \cdot \mathrm{Ch}_{\mathrm{SML}}}\right) \cdot W \cdot f \\
& a=0.0308 \cdot \mathrm{e}^{0.0369 \cdot T} \\
& r=0.1585 \cdot \mathrm{e}^{0.1126 \cdot T}
\end{aligned}
$$

where $\mathrm{Chl}_{\mathrm{SML}}$ is the simulated chl a concentration (mg chl $a^{-3}$ ) in the surface mixed layer, $W$ is wet mass $(\mathrm{mg}), f$ represents the feeding time budget (hours out of $24 \mathrm{~h}$ ) and $T$ is ambient water temperature. Time series of surface water temperature from Palmer Station (US Antarctic Program) and Rothera Base (British Antarctic Survey) for 2001 and 2002 were used as input for temperature-dependent processes (Fig. 1). $W$ is calculated from total body length $L_{r}(\mathrm{~mm})$, with an equation fit to data from cruises in austral fall (April 1985, April 1986) and winter (June to July 1987, SO GLOBEC 2001, SO GLOBEC 2002) ( $\mathrm{n}=401, \mathrm{r}^{2}=0.94$, data not shown). $L$ and $W$ were measured as described in Ross et al. (2004). The relationship is:

$$
W=0.0100 \cdot L^{2.8096}
$$

In the model, larval krill fed among 3 food habitats: surface mixed layer, deep-water column below the surface mixed layer and sea ice. In the surface mixed 


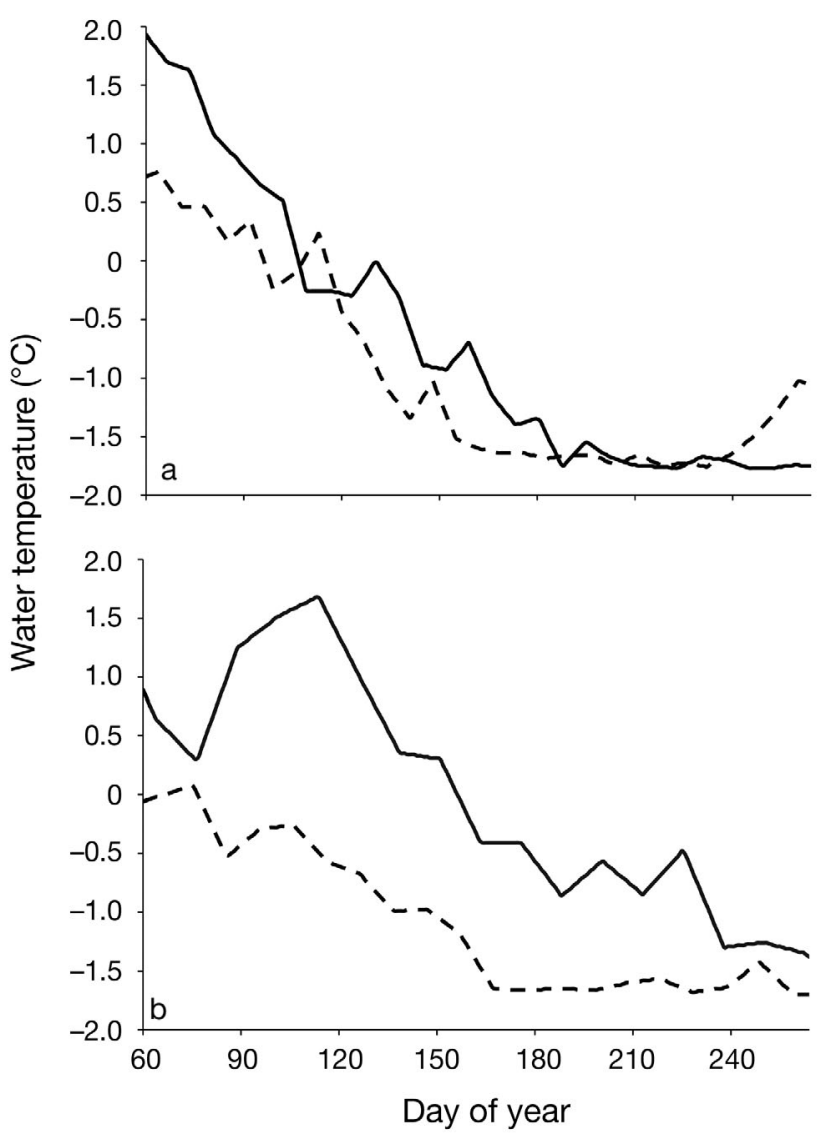

Fig. 1. Time series of surface water temperature. (a) A $7 \mathrm{~d}$ running average of daily temperature measurements was taken at the Palmer Station tide gauge from 2001 (solid) and 2002 (dashed), courtesy of Palmer Station and the National Science Foundation, conveyed by B. Pickering. (b) Weekly measurements of surface water temperature at Rothera Base from 2001 (solid) and 2002 (dashed), courtesy of A. Clarke, British Antarctic Survey

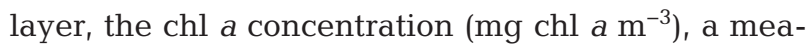
sure of autotrophic biomass, was an output of the phytoplankton dynamics model developed by Vernet et al. (2012) (Fig. 2). Initial water column chl a concentrations for larval krill simulations, estimated from seasonal measurements, were 1.035 and $4.5 \mathrm{mg}$ chl $a \mathrm{~m}^{-3}$ for Palmer Basin 2001 and 2002, and 1 and

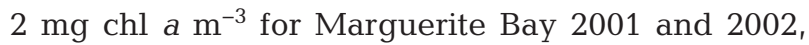
respectively. The deep-water column and sea icecovered surface layers are stable environments with low chl a concentrations. The chl $a$ available in these habitats was held constant at $0.025 \mathrm{mg} \mathrm{m}^{-3}$ in the deep-water column and $0.03 \mathrm{mg} \mathrm{m}^{-3}$ in the sea icecovered surface layer (L. Quetin \& R. Ross unpubl. data). Water column chl a was converted to carbon with a carbon to chl a ratio (C:chl a) of 75 initially, which decreased to 50 on June 1 to reflect the physio- logical adaptation of phytoplankton to low light. $\mathrm{C}: \mathrm{chl}$ a was determined by analysis of community carbon composition and measured as chl a. An empirically derived loss rate was used to fit the demise of phytoplankton biomass to data from Palmer LTER and SO GLOBEC austral falls of 2001 and 2002 (Vernet et al. 2012). The loss rate included grazing by the entire zooplankton community, advection and sedimentation.

During the austral spring of 2002, experiments were conducted at Palmer Station to simulate the grazing behavior of larval krill on SIMCOs by quantifying ingestion of phytoplankton grown on a surface (Oakes 2008). The rate of SIMCO ingestion derived from these experiments was:

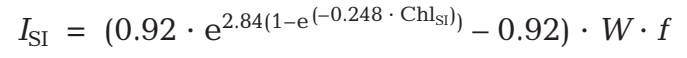

where $\mathrm{Chl}_{\mathrm{SI}}$ was the simulated chl a concentration in the sea ice (Fig. 2). The SIMCO dynamics model was developed by Fritsen et al. (1998) and parameterized and run with environmental conditions specific to Palmer Basin and Marguerite Bay in 2001 and 2002. Sea ice chl a was converted to carbon with a C:chl a ratio of 80 throughout the simulation. Larval krill in the model were assumed to associate with the sea ice at $\geq 30 \%$ cover due to the combined effect of changes in light intensity and availability of SIMCOs and physical habitat. Sea ice cover at each location was derived from bootstrap sea ice concentrations from Nimbus-7 SMMR and DMSP SSM/I data (Comiso 1999, updated 2008).

\section{Feeding behavior}

Under sea ice-free conditions larval krill exhibit DVM between the surface at night and deeper water during the day (Fraser 1936, Nast 1978). Observations of gut pigment from larvae in open water indicate diel feeding patterns that could reflect migration to the surface mixed layer at night and to depth during daylight (Meyer et al. 2003, Pakhomov et al. 2004). In contrast, larval krill associated with sea ice have been observed to exhibit a reversed DVM, descending into the water column at night and associating with the sea ice during the day. Quetin et al. (2003) identified a relationship between larval growth rate and daylength, possibly related to lightdependent behavior, changes in carbon allocation or seasonal dynamics of primary productivity. Simulated larval krill with unlimited access to $\mathrm{Chl}_{\mathrm{SML}}$ and $\mathrm{Chl}_{\mathrm{SI}}$ exhibited unrealistic carbon assimilation and 


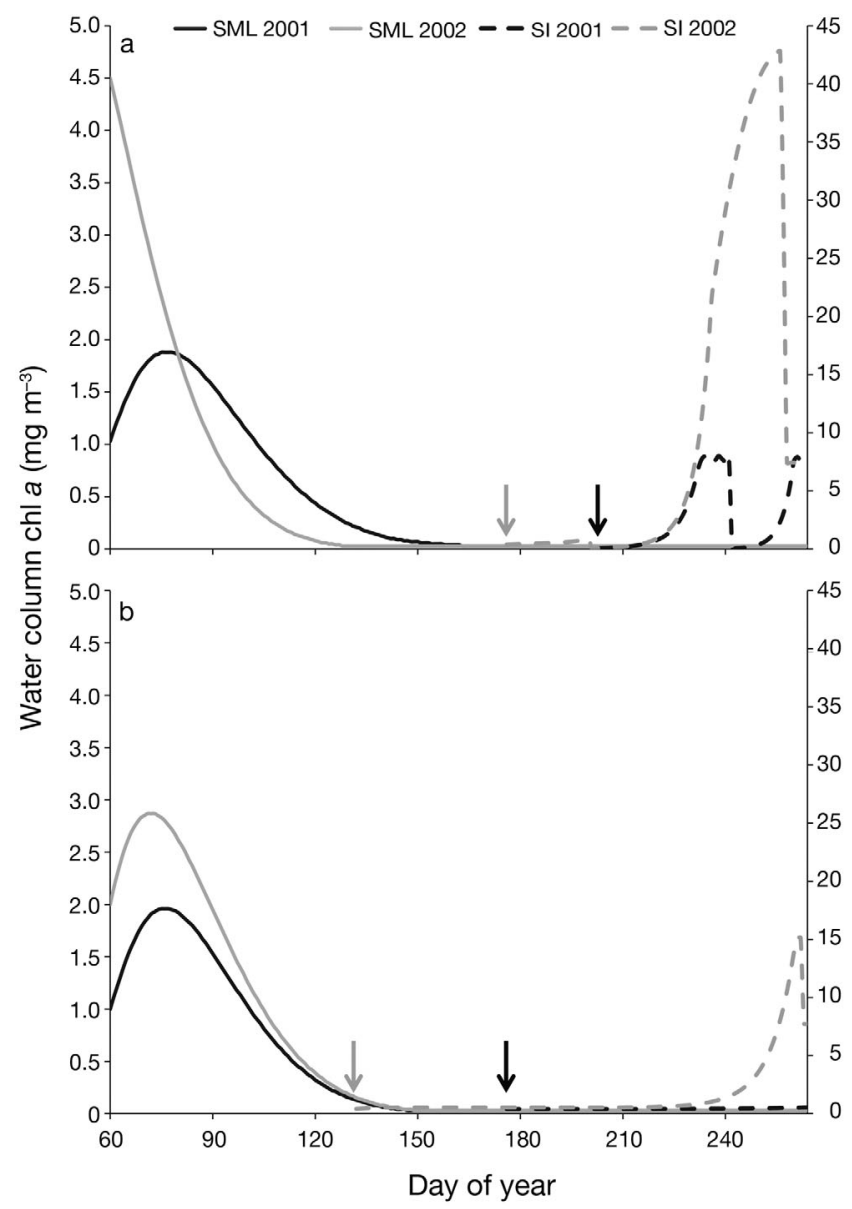

Fig. 2. Euphausia superba. Time series of simulated food availability (mg chlorophyll $a^{-3}$ ) for Antarctic krill in the surface mixed layer (SML) from Vernet et al. (2012) (solid line) and sea ice (SI) from Fritsen et al. (1998) (dashed line) for (a) Palmer Basin, 2001 (black) and 2002 (gray), and (b) Marguerite Bay, 2001 (black) and 2002 (gray). Arrows indicate day of sea ice advance

growth rates, indicating decreased primary productivity and carbon allocation alone were not driving the daylength-growth relationship. Light-driven DVM was therefore incorporated into the model to constrain carbon assimilation rate with observed behavior.

The amount of time spent feeding in each habitat, $f$, (Eqs. $2 \& 4$ ) is a function of sea ice cover and the fraction of daylength spent feeding per $24 \mathrm{~h}$ period (Table 2). The feeding fraction, $t$, is greater than the daylength fraction, $D F$, to account for observations of larval krill migrating before sunrise and after sunset in fall and winter $(t=1.3 D F)$. Daylength, defined as the number of hours between sunrise and sunset, is a function of day of the year and latitude. The resulting behavior varies seasonally from standard DVM in fall
Table 2. Euphausia superba. Rules of diel vertical migration (DVM) of krill determining feeding time budget, $f$. Daylength fraction, $D F$, is daylight hours per $24 \mathrm{~h}$ period and feeding fraction, $t$, represents the fraction of the day krill spent feeding in the surface mixed layer, deep-water column or sea ice food habitat $(t=1.3 D F)$. Presence of sea ice was defined as $\geq 30 \%$ cover. - not applicable

\begin{tabular}{|lcccc|}
\hline \multirow{2}{*}{$\begin{array}{l}\text { Daylength } \\
\text { fraction }\end{array}$} & Sea ice & \multicolumn{3}{c|}{ Feeding time budget -} \\
\cline { 3 - 5 }$>0.2$ & present? & Surface & Deep & Sea ice \\
\hline \multirow{2}{*}{$<0.2$} & Yo & $1-t$ & $t$ & - \\
& No & $1-t$ & - & $t$ \\
& Yes & 1 & 0 & - \\
\hline
\end{tabular}

through a transition period of no DVM during minimum daylength $(D F<0.2)$ to reversed-DVM in late winter under the sea ice (Table 2).

\section{Carbon losses}

Loss terms in the carbon budget of individual krill include respiration and egestion of unassimilated material. Carbon losses due to sloppy feeding, molting and excretion of organic carbon are not included, as empirical estimates of the magnitude of these losses are currently unavailable or assumed to be minimal (molting).

Temperature-dependent respiration rate was derived from measurements of oxygen consumption in experiments conducted during the winter of 1993 (Fig. 3, re-analysis of experimental data from Frazer et al. 2002). The temperature effect for larval krill acclimated to experimental temperatures for weeks was less than that of krill acclimated for $24 \mathrm{~h}$ and was assumed to better represent larval respiration in the environment. The effect of wet mass on respiration rate was not significant and a weight exponent of 1 was used for this size range. The relationship for temperature-dependent respiration rate $\left(\mu \mathrm{O}_{2} \mathrm{krill}^{-1} \mathrm{~h}^{-1}\right)$ is:

$$
R=0.141 \cdot \mathrm{e}^{0.1017 \cdot T} \cdot W
$$

where moles of $\mathrm{O}_{2}$ consumed are converted to $\mathrm{CO}_{2}$ produced with a respiratory quotient of 0.72 , which reflects primarily lipid metabolism (Ikeda \& Bruce 1986). $\mathrm{CO}_{2}$ produced was converted to $\mathrm{C}\left(\mu \mathrm{g} \mathrm{C} \mathrm{krill}^{-1}\right.$ $\mathrm{h}^{-1}$ ) to be consistent with carbon budget equations.

Egestion was calculated from assimilation efficiency $(A E)$ as:

$$
E g=(1-A E) \cdot\left(I_{\mathrm{WC}}+I_{\mathrm{SI}}\right)
$$




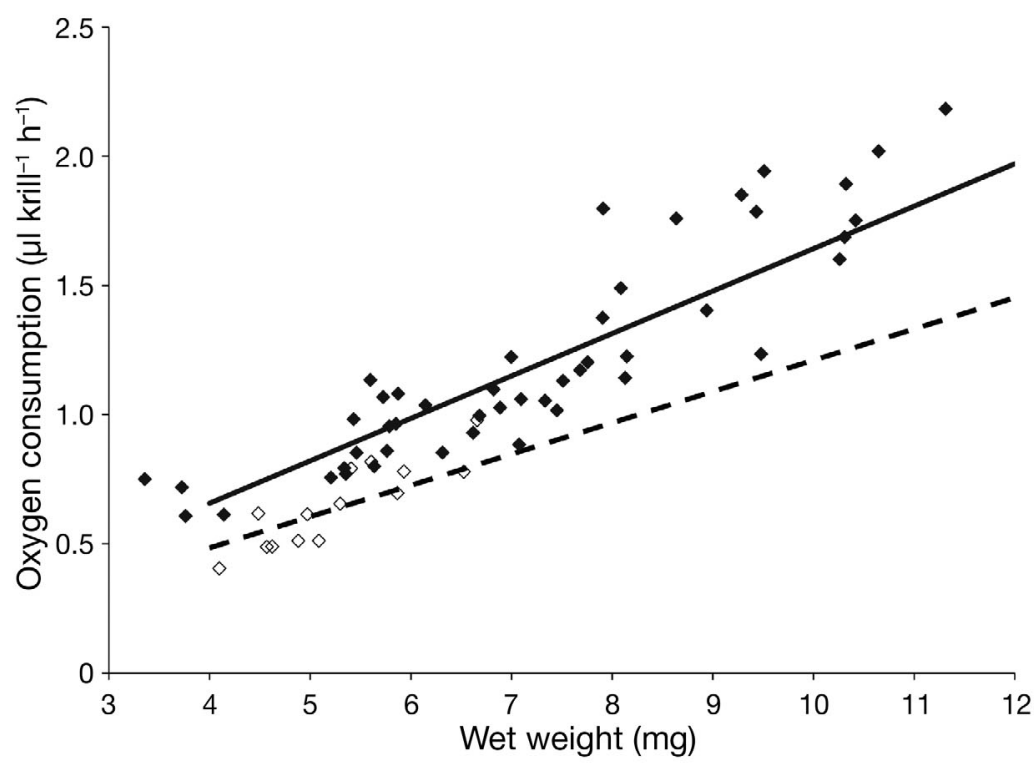

Fig. 3. Euphausia superba. Measured (points) and predicted (lines) weightspecific oxygen consumption rate of larval krill acclimated at $-1.5^{\circ} \mathrm{C}$ (open symbols, dashed line) and $+1.5^{\circ} \mathrm{C}$ (solid symbols, solid line), a re-analysis of Frazer et al. (2002). Predicted values are from Eq. (5)

veloped in an attempt to reproduce the seasonal pattern observed in Fig. 4. The relationship among total body carbon, length and $C F$ was used to simulate growth as a function of net assimilated carbon, $\Delta C_{\mathrm{b}}$. Growth was calculated as

$\Delta L=\alpha\left[\left(\frac{\Delta C_{\mathrm{b}}+C_{\mathrm{b}(p-1)}}{C_{\mathrm{b}(p-1)}}\right)^{(1 / 3)}-1\right] \cdot L_{(p-1)}$

where $\alpha$ was a carbon-partitioning constant that apportions carbon between structural tissue (i.e. body length, $L$ ) and energy reserves $(C F)$, and $p$ is the present simulation time point. The relationship allowed positive and negative growth dependent on carbon assimilation rate and $C F$ (Table 3 ). This formulation allowed both $L$ and $C F$ to vary in response to assimilation of new carbon or utilization of stored carbon. Positive growth occurred when $\Delta C_{\mathrm{b}}$ was greater than 0 and $C F$ was greater than 0.55 . During positive growth, $70 \%$ of assimi-

Assimilation efficiency was found to range from 0.70 to 0.91 and was not correlated to carbon availability (Oakes 2008). The average of 0.80 was used in this study.

\section{Growth dynamics}

Historical observations of growth rate and $C F$ from individual krill exhibited a seasonal pattern throughout fall and winter (Fig. 4). During the fall CF was generally high and growth rates were positive across a range of $C F$. Following the decline of the fall phytoplankton biomass, $C F$ declined and growth rates decreased to and remain near 0 or slightly negative until late winter (Quetin et al. 2003, Ross et al. 2004). Shrinkage was only observed in individuals with $C F$ less than 0.55 , the $C F$ at which point negative growth could occur in the model (Fig. 4). In experiments with larval krill kept in filtered water, the $C F$ at which half of the larvae died was near 0.35 (L. B. Quetin \& R. M. Ross unpubl. data). Field observations also suggested few krill survive below a CF of 0.35 (Fig. 4). Based on these observations, model larvae starved if $C F$ decreased below 0.35 (referred to as $\mathrm{CF}_{0.35}$ ).

The seasonal relationship between growth rate and $C F$ indicated there was a prioritization of carbon allocation related to environmental conditions, primarily food availability. Growth rules in the model were de- lated carbon was partitioned to growth and $30 \%$ to $C F$ $(\alpha=0.7)$. When $\Delta C_{\mathrm{b}}$ was negative and $C F$ was above 0.55 , carbon for maintenance was drawn from energy reserves, which reduces $C F$ while allowing $L$ to remain constant. When $\Delta C_{\mathrm{b}}$ was negative and $C F$ was below 0.55 , both structural carbon and energy reserves were utilized in equal proportions $(\alpha=0.5)$ to meet respiratory demand. The result was a simultaneous decline in $L$ and $C F$. Simulations were allowed to continue after $C F_{0.35}$ was reached in order to observe patterns of physiological condition later in the season.

\section{Model simulations}

The model was used to explore the influence of environmental variability on physiological condition (growth rate and $C F$ ) of larval krill across spatial (latitudinal) and temporal (seasonal and inter-annual) scales. Physiological condition of larval krill throughout the season was also described by the day at which net assimilated carbon became negative $\left(\Delta C_{\mathrm{b}}<0\right)$, total body carbon decreased to $50 \%$ of fall maximum, $C_{\text {max }}, C F$ declined to $C F_{0.35}$, and the duration of negative $\Delta C_{\mathrm{b}}$.

Simulations ran from March 1 to the end of austral winter on September 21. Length and condition factor measurements from March 2001 and 2002 were not available; therefore, a sample cohort was created 


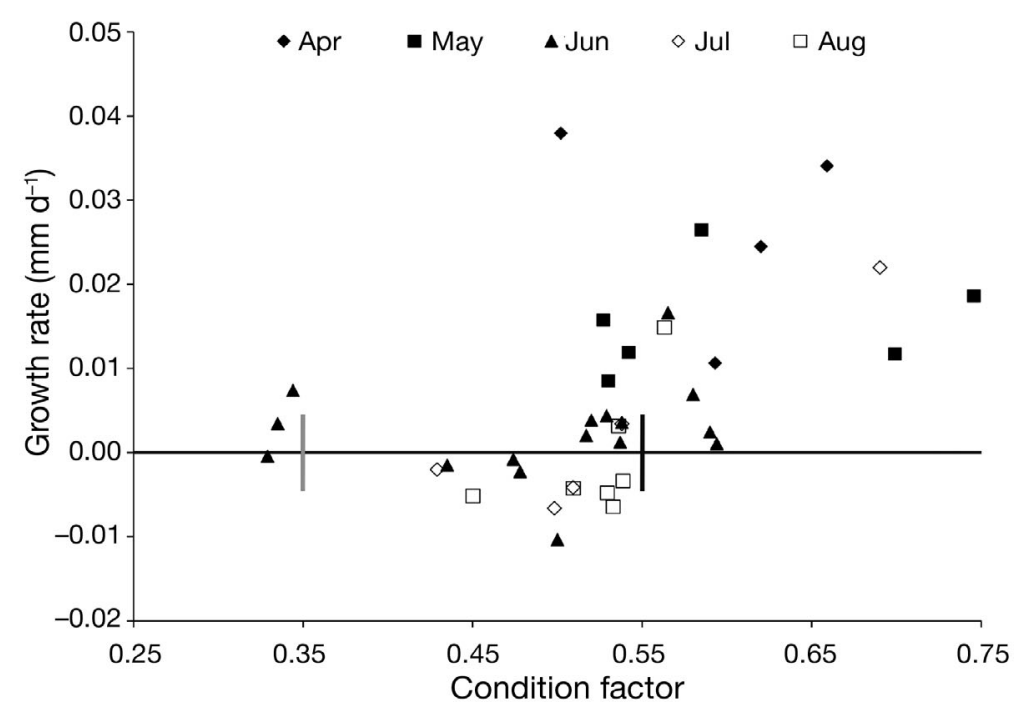

Fig. 4. Euphausia superba. Historical observations of growth rate and condition factor $(C F)$ from larval krill collected in April 1988 and 1993, May 1991 and 1993, June 1987, 1993, 1994 and 1999, July 1987, 1989, 1994 and 2001, and August 2001 and 2002. Mean CF and growth rate values are from larvae collected at the same time and location. $C F$ was determined as described in Ross \& Quetin (1991). Growth rates were modified from Quetin et al. (2002) with an updated algorithm for the intermolt period as a function of day of year to include SO GLOBEC data (Eq. 8). Horizontal line indicates zero growth. Vertical bars indicate $C F_{0.35}$ (gray) and the growth threshold (black)

Table 3. Euphausia superba. Rules for linear growth of krill as a function of assimilated carbon and $C F$, based on historical observations of growth rate and $C F$ of krill during fall and winter (shown in Fig. 5)

\begin{tabular}{|lc|}
\hline Direction of growth & Conditions \\
\hline Positive & If $\Delta C_{\mathrm{b}}>0$ and $C F \geq 0.55$ \\
Negative & If $\Delta C_{\mathrm{b}}<0$ and $C F<0.55$ \\
Zero & If $\Delta C_{\mathrm{b}}>0$ and $C F<0.55$ \\
& if $\Delta C_{\mathrm{b}}<0$ and $C F>0.55$ \\
& or if $\Delta C_{\mathrm{b}}=0$ \\
\hline
\end{tabular}

from frequency distributions of larval krill collected in late February 1988 for length $(\mathrm{n}=190, \mu=$ $6.96 \mathrm{~mm}, \sigma=0.89$ ) and early April 1988 and 1993 for $C F(\mathrm{n}=277, \mu=0.56, \sigma=0.12)$. Two simulations were run. First, the physiological condition of an averagesized larval krill from the sample cohort was simulated in 4 scenarios with environmental conditions from Palmer Basin 2001 and 2002 and Marguerite Bay 2001 and 2002. Daily growth rate, $L$ and $C F$ were integrated over the simulated intermolt period (IMP). IMP is a function of day of year, $D$, according to the following algorithm modified from Quetin et al. (2003) to include SO GLOBEC data:

$$
\mathrm{IMP}=-0.0015 \cdot D^{2}+0.5944 \cdot D-25.93
$$

A survival index was created to extrapolate linkages between environmental variability and the physiological condition of larvae to the cohort level. The percentage that survived each simulation illustrates relative survival rates and recruitment potential among scenarios. A cumulative density distribution was constructed to calculate the percentage of larval krill surviving the simulation. Larval krill were divided into $0.1 \mathrm{~mm}$ length increments from 5.16 to $8.76 \mathrm{~mm}( \pm 2 \mathrm{SD}$ from the mean) and $0.05 C F$ increments from 0.35 to 0.95 (the range of measured $C F$ ). A matrix was created with each element representing the product of the cumulative probability of the $C F$ increment and the standardized proportion of the length increment, such that the sum of the proportions was equal to 1 at the beginning of the simulation. If $C F$ of a larva reached 0.35 , starvation was considered to have occurred and that proportion was subtracted from the distribution. Mortality in the index only resulted from starvation; effects of predation, advection and active migration out of the population were not addressed.

Second, experimental simulations were run with manipulated phytoplankton and SIMCO availability curves to further investigate the effect of food availability on the physiological condition of an averagesized larval krill. Fall phytoplankton dynamics from 2001 were combined with SIMCO dynamics from 2002, and vice versa, for Palmer Basin and Marguerite Bay.

\section{RESULTS \\ Effects of environmental variability on average krill}

In general, food availability followed a similar pattern to daylength. Food availability was highest in the fall and late winter, which corresponded to the fall phytoplankton bloom and the SIMCO bloom, and minimum food concentrations occurred by midwinter (Fig. 2). Differences in the initial chl a concentration, rate of fall phytoplankton decline, timing of sea ice advance and SIMCO dynamics led to variability in the physiological condition and survival of larval krill. 
In all scenarios, negative $\Delta C_{\mathrm{b}}$ first occurred during the fall phytoplankton decline and continued until SIMCO chl a concentrations increased in late winter (Table 4). Average carbon intake required for maintenance during the fall $\left(\Delta C_{\mathrm{b}}=0\right)$ ranged from $0.35 \mu \mathrm{g}$ $\mathrm{C}_{\mathrm{krill}}{ }^{-1} \mathrm{~h}^{-1}$ in Palmer Basin 2002 to $0.47 \mu \mathrm{g} \mathrm{C} \mathrm{krill}^{-1}$ $\mathrm{h}^{-1}$ in Marguerite Bay 2002. Growth rates responded rapidly to changes in food concentration and tightly followed the seasonal pattern in food availability (Figs. 5a \& 6a). CF responded quickly to increases in food concentration, but lagged behind decreases in food concentration (Figs. 5b \& 6b).

In Palmer Basin 2001 (PB2001), fall phytoplankton biomass declined slowly, leading to positive $\Delta C_{\mathrm{b}}$ until Day 127 (Table 4). Sea ice advance occurred late in the winter, delaying the availability of SIMCOs to larval krill. As a result, total body carbon decreased to $50 \%$ of the fall maximum, $C_{\max }$, by Day 193 and negative growth rates continued for nearly 2 mo (Fig. 5a). Larval krill had an average growth rate of $0.014 \mathrm{~mm} \mathrm{~d}^{-1}$ over the simulation period (Table 5). $C F$ peaked on Day 126 and decreased slowly until late winter, but never decreased below $C_{0.35}$ (Fig. 5b). The SIMCO bloom in August led to recovery of growth rate and $C F$ (Fig. 5). Larvae in PB2001 had an average daily carbon accumulation of $1.6 \mu \mathrm{g} \mathrm{C} \mathrm{d}^{-1}$ and a final $C F$ of 0.60 .

In Palmer Basin 2002 (PB2002), fall phytoplankton biomass declined rapidly, resulting in early food limitation (Fig. 2a). Negative $\Delta C_{\mathrm{b}}$ occurred on Day 103 and larval krill lost $50 \%$ of $C_{\max }$ by Day 164 (Table 4). Growth rate reached 0 by Day 111 and became negative by Day 130 (Fig. 5a). CF declined to $C F_{0.35}$ by Day 201 (Fig. 5b). The SIMCO bloom in early August 2002 made high concentrations of chl a available, which led to the highest average carbon assimilation and growth rates observed among all scenarios (6.72 $\mu \mathrm{g} \mathrm{C} \mathrm{d}^{-1}$ and $0.020 \mathrm{~mm} \mathrm{~d}^{-1}$, respectively). The final $C F$ was 0.96. Although food limitation began

Table 4. Euphausia superba. Characteristics of net assimilated carbon $\left(\Delta C_{\mathrm{b}}\right)$ and $C F$ of an average-sized larval krill and day of occurrence. $C_{\max }$ is defined as the maximum total body carbon in fall. $C F_{0.35}$ is the point when $C F$ is equal to 0.35. PB: Palmer Basin; MB: Marguerite Bay

\begin{tabular}{|lcccc|}
\hline \multirow{2}{*}{ Characteristic } & \multicolumn{4}{c|}{ Region and year } \\
\cline { 2 - 5 } & PB2001 & PB2002 & MB2001 & \multirow{2}{*}{ MB2002 } \\
\hline Day $\Delta C_{\mathrm{b}}<0$ & 127 & 103 & 123 & 126 \\
Day at $50 \%$ of $C_{\max }$ & 193 & 164 & 185 & 233 \\
Day at $C F_{0.35}$ & Never & 201 & 221 & Never \\
Duration $(\mathrm{d}) \Delta C_{\mathrm{b}}<0$ & 91 & 114 & 142 & 111 \\
\hline
\end{tabular}

earlier and lasted longer in 2002, the SIMCO bloom in August yielded high enough growth rates that final length of krill was greater in 2002 (11.04 mm) than in 2001 (9.87 $\mathrm{mm})$.

In Marguerite Bay 2001 (MB2001) and 2002 (MB2002) fall phytoplankton biomass declined slowly and was soon followed by sea ice advance and the development of SIMCOs (Fig. 2b). In MB2001, $\Delta C_{\mathrm{b}}$ became negative on Day 123 and larval krill lost $50 \%$ of $C_{\max }$ by Day 185 (Table 4). Growth rate was positive until Day 166 (Fig. 6a). Food limitation after the advance of sea ice led to the decline to $C_{0.35}$ by Day 221 (Table 4). Elevated water temperature (Fig. 1) led to increased respiration and contributed to the rapid decrease of $C F$ before sea ice advance (Fig. 6b). SIMCO biomass did not increase in late winter, and total length and $C F$ decreased until September 21. Larval krill in this scenario had the lowest average growth rate $\left(0.002 \mathrm{~mm} \mathrm{~d}^{-1}\right.$, Table 5) and a negative average carbon assimilation rate $\left(-0.43 \mu \mathrm{g} \mathrm{C} \mathrm{d}^{-1}\right)$.

In MB2002, $\Delta C_{\mathrm{b}}$ decreased below 0 by Day 126 yet larvae maintained more than $50 \%$ of total body carbon until Day 233 (Table 4). Negative growth rates did not occur until Day 197 and persisted only for $42 \mathrm{~d}$ (Fig. 6a). Average growth rate of krill over the simulation period was $0.016 \mathrm{~mm} \mathrm{~d}^{-1}$ (Table 5). Sea ice advance overlapped the fall phytoplankton decline and SIMCO biomass increased in late winter, resulting in good physiological condition throughout the winter, as $C F$ never decreased to $C F_{0.35}$ (Fig. 6b). The differences in late winter sea ice algal dynamics resulted in a large difference in final length of krill between MB2001 (7.34 mm) and MB2002 (10.28 mm).

Larval respiration rates in the simulations ranged between 1.29 and $1.87 \mu \mathrm{g} \mathrm{C} \mathrm{mg} W^{-1} \mathrm{~d}^{-1}$ (reflecting a total carbon loss, due to respiration, of 3.12 to 10.32 $\mu \mathrm{g} \mathrm{C} \mathrm{krill}{ }^{-1} \mathrm{~d}^{-1}$ ). Winter respiration rates were 17 to $32 \%$ lower than in fall. In general, respiration was highest in early fall and slowly decreased with temperature throughout the winter. MB2001 was an exception, however, in that respiration increased until Day 110 and continued to be higher than the other scenarios, a result of the anomalously high water temperature. Total carbon loss due to respiration also depended on wet weight, which increased as krill grew and decreased when extreme food limitation resulted in shrinkage. 

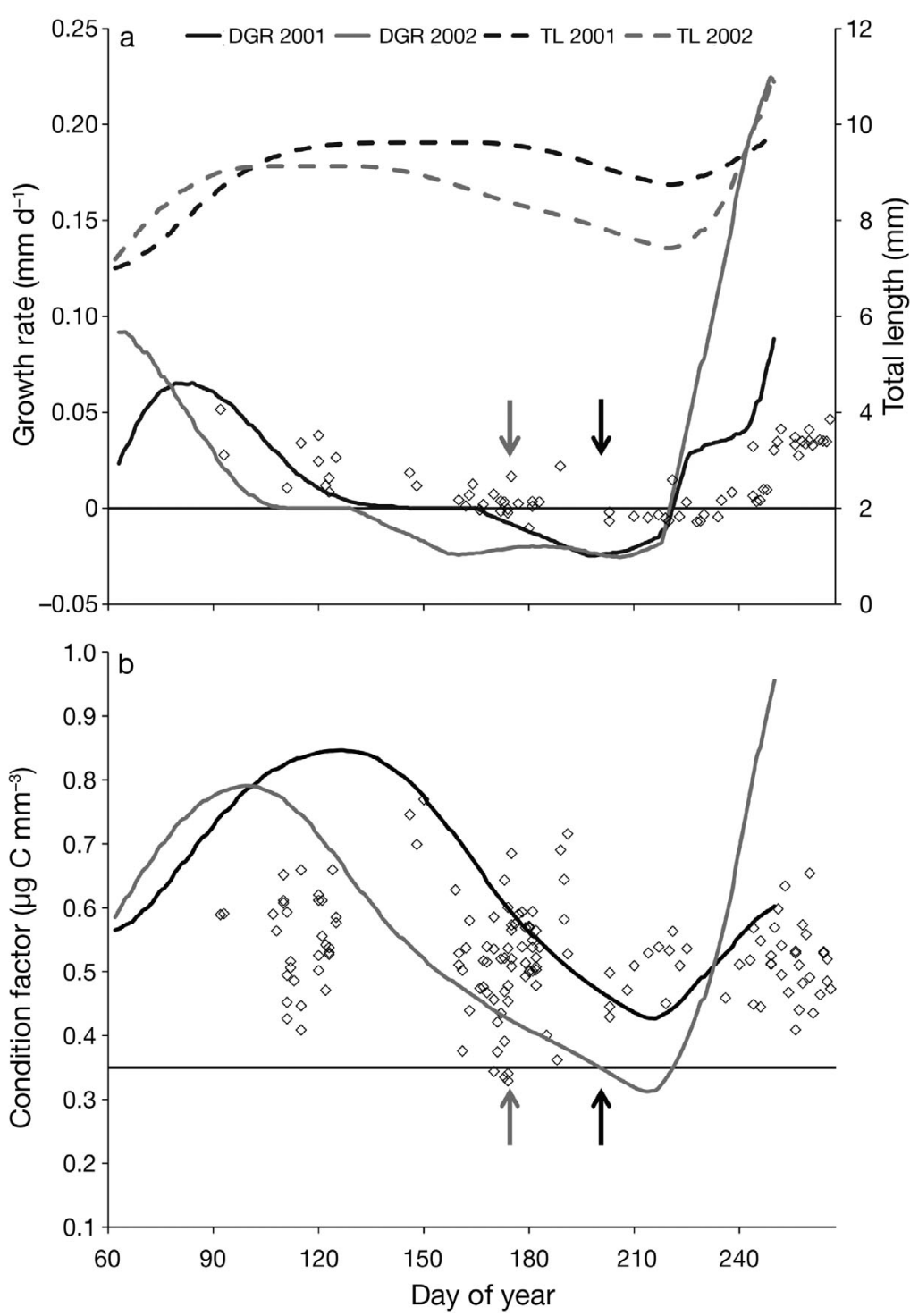

Fig. 5. Euphausia superba. Modeled (a) total length (TL, dashed line) and daily growth rate (DGR, solid line) and (b) condition factor $(C F)$ of larval krill in Palmer Basin in 2001 (black) and 2002 (gray). Individual symbols mark observations of growth and $C F$ as in Fig. 3. Additional observations of $C F$ were made in September 1991, 1993, 2001 and 2002. TL and DGR were averaged over the intermolt period (Eq. 8). Horizontal line indicates zero growth in (a) and $\mathrm{CF}_{0.35}$ in (b). Arrows correspond to day of sea ice advance

In the survival index, the percent of the cohort surviving the winter differed greatly between years and ranged from 1.85 to $100 \%$ (Fig. 7). The slow phytoplankton decline and greater fall food availability in PB2001 led to high survival in winter (Table 6, Fig. 7a). The only mortality in PB2001 occurred during the period before the SIMCO bloom (Table 6). In PB2002, the rapid fall phytoplankton decline resulted in early food limitation and starvation occurred in July and August (Table 6, Fig. 7b). In both PB2001 and PB2002, percent survival remained constant following the August SIMCO bloom, which corresponded to the increased availability of food.

Differences in survival in Marguerite Bay were driven by late winter SIMCO dynamics. In both MB2001 and MB2002, the slow phytoplankton decline provided a food source until SIMCOs became available in winter, which resulted in high survival through July (Table 6). However, the lack of a SIMCO bloom in MB2001 led to extreme food limitation, and less than $2 \%$ of the cohort survived in the simulation (Table 6). In this simulation, larval krill entering the fall with a higher $C F$ exhibited greater tolerance to starvation and had higher survival rates (Fig. 7c). Conditions in MB2002 represented ideal conditions for larval survival as $100 \%$ survived (Table 6, Fig. 7 d).

\section{Manipulated environmental conditions}

The rate of decline of fall phytoplankton biomass was important for maintaining total body carbon, and thus $C F$, into the winter. A slow phytoplankton decline provided sufficient carbon for krill to maintain $C F$ above $C_{0.35}$ in all simulations. Manually combining a slow phytoplankton decline with early sea ice advance resulted in a higher minimum $C F$ and delayed the loss of $50 \%$ of $C_{\max }$ by $7 \mathrm{~d}$ compared with a later sea ice advance (timing of sea ice advance from PB2002 versus PB2001). In contrast, larvae lost $50 \%$ of $C_{\max }$ before sea ice advance in all simulations following a rapid fall phytoplankton decline. A rapid phytoplankton decline followed by late sea ice advance led to $C F$ decreasing to $C F_{0.35} 9 \mathrm{~d}$ earlier than when sea ice advanced at an earlier date. Physiological condition recovered if a SIMCO bloom occurred, but continued to decline if a SIMCO bloom did not occur. Addition of SIMCO biomass to MB2001 resulted in recovery of $C F$, although not before decreasing to $C F_{0.35}$. Removal of the SIMCO bloom from MB2002 resulted in continued decline of $C F$ to a minimum of 0.43 at the end of the simulation. 


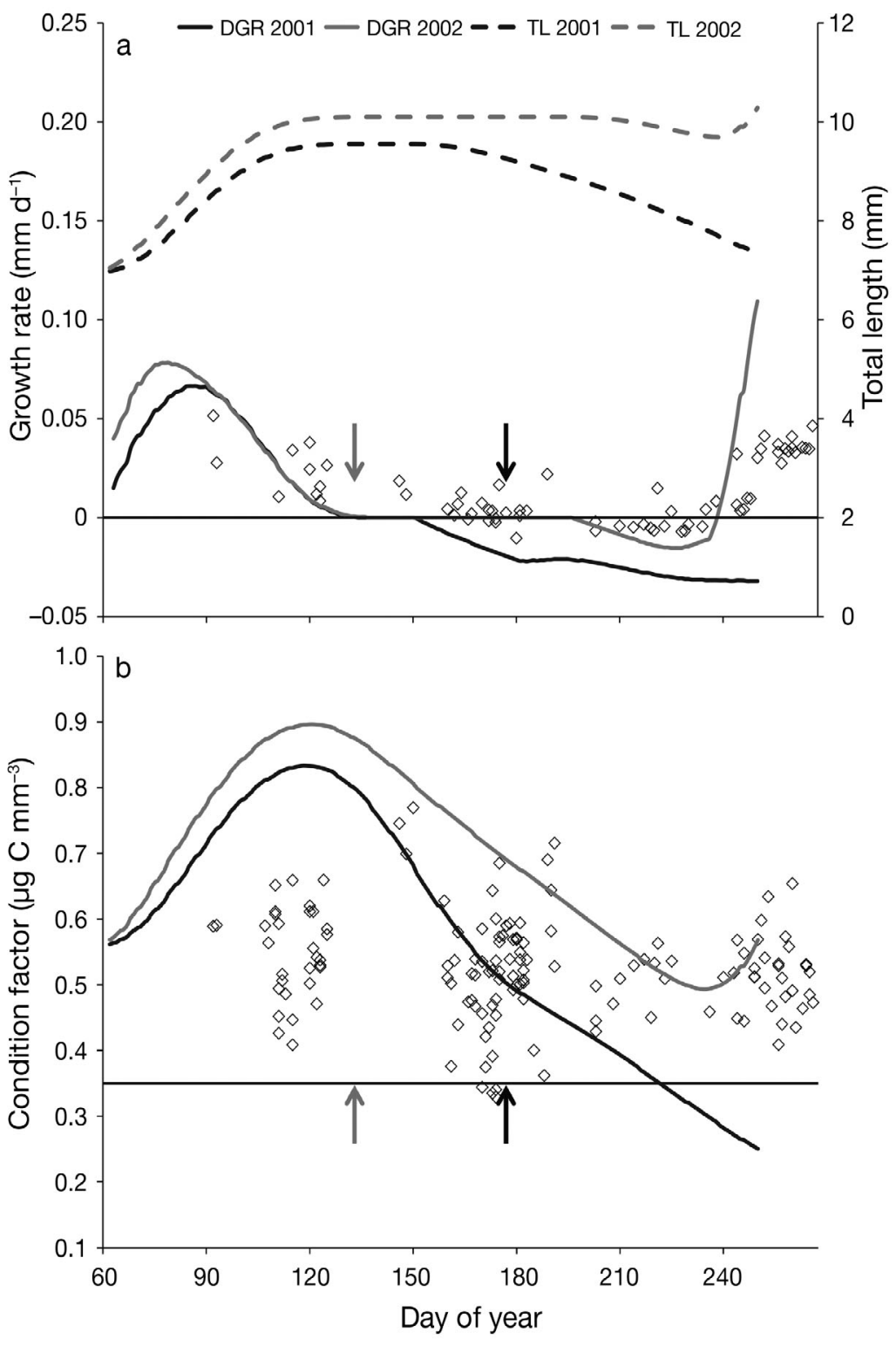

Fig. 6. Euphausia superba. Modeled (a) total length (TL, dashed line) and daily growth rate (DGR, solid line) and (b) $C F$ of larval krill in Marguerite Bay in 2001 (black) and 2002 (gray). TL and DGR were averaged over the intermolt period (Eq. 8). Horizontal line indicates zero growth in (a) and $\mathrm{CF}_{0.35}$ in (b). Arrows correspond to day of sea ice advance. Historical observations as in Fig. 5

Table 5. Euphausia superba. Simulated daily growth rates $\left(\mathrm{mm} \mathrm{d}^{-1}\right)$ of an average-sized larval krill. PB: Palmer Basin; MB: Marguerite Bay

\begin{tabular}{|lcccc|}
\hline \multirow{2}{*}{ Rate category } & \multicolumn{4}{c|}{ Region and year } \\
\cline { 2 - 5 } & PB2001 & PB2002 & MB2001 & MB2002 \\
\hline Minimum & -0.025 & -0.025 & -0.032 & -0.015 \\
Maximum & 0.088 & 0.224 & 0.066 & 0.109 \\
Average & 0.014 & 0.020 & 0.002 & 0.016 \\
\hline
\end{tabular}

\section{Sensitivity analysis}

Larval krill dynamics were sensitive to changes to the rate of phytoplankton decline in fall and the $\mathrm{C}: \mathrm{chl}$ a ratio of available food in the water column and sea ice. A $20 \%$ increase or decrease in phytoplankton loss factor resulted in a $29 \%$ decrease or $40 \%$ increase in total length at the end of the simulation relative to the average-krill simulation. Average daily growth rate in these simulations was 0.003 and $0.040 \mathrm{~mm} \mathrm{~d}^{-1}$, respectively. A $20 \%$ increase or decrease in the C:chl a ratio produced a $35 \%$ increase or $32 \%$ decrease in the total length, respectively, at the end of the simulation. Simulations using the range of measured $A E$ (0.7 and 0.91, representing $\sim 13 \%$ change in $A E$ ), resulted in less than $20 \%$ change in final total length. The $C F$ of krill in the model was also sensitive to a decrease in phytoplankton loss factor and positive $\alpha$, but varied over a much smaller range than did total length ( -7 to $+19 \%$ for a $20 \%$ change in initial value). Timing of DVM also had a large effect on the magnitude of growth rates and $C F$ during winter, as a function of the amount of time krill spent feeding on the sea ice. However, the range of behavior tested did not change the observed seasonal pattern in growth rate and $C F$. Changes to initial values of other environmental and physiological parameters (Table 1) did not considerably alter the final length and $C F$.

\section{DISCUSSION}

\section{General model performance}

Total length and growth rates of larval krill were within the range of historical observations from the wAP in fall and winter (Table 5, Figs. 5 \& 6) (Quetin et al. 2003, Daly 2004, Ross et al. 2004). Modeled growth rates followed a similar seasonal trend in the start date and duration of zero or negative growth as larvae in other growth models (Hofmann \& Lascara 2000, Fach et al. 2008). However, the 


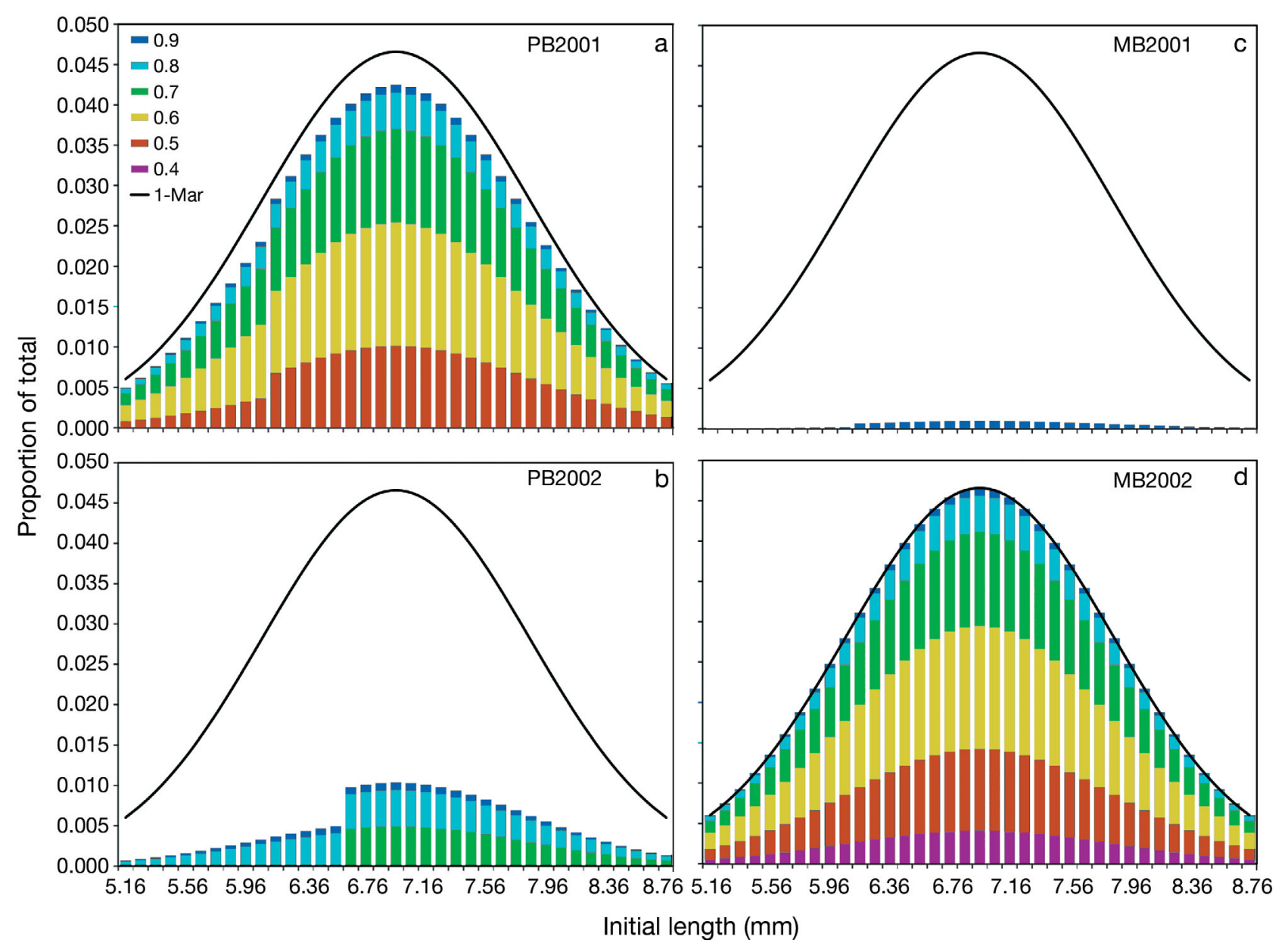

Fig. 7. Euphausia superba. Interannual comparison of krill cohort survival. Solid curve indicates initial population on March 1. Histogram illustrates final proportion of larvae surviving, binned by initial length (column) and condition factor (CF) (various gray shading) in (a) Palmer Basin 2001, (b) Palmer Basin 2002, (c) Marguerite Bay 2001 and (d) Marguerite Bay 2002

Table 6. Euphausia superba. Percent survival of simulated sample cohort, defined as the percentage of initial population having maintained $C F$ above 0.35 to the date indicated. PB: Palmer Basin; MB: Marguerite Bay

\begin{tabular}{|lcccc|}
\hline \multirow{2}{*}{ Date } & \multicolumn{4}{c}{ Region and year } \\
\cline { 2 - 5 } & PB2001 & PB2002 & MB2001 & MB2002 \\
\hline 01 Mar & 100 & 100 & 100 & 100 \\
01 Apr & 100 & 100 & 100 & 100 \\
01 May & 100 & 100 & 100 & 100 \\
01 Jun & 100 & 100 & 100 & 100 \\
01 Jul & 100 & 100 & 100 & 100 \\
01 Aug & 100 & 34.9 & 99.9 & 100 \\
01 Sep & 89.8 & 18.7 & 12.0 & 100 \\
21 Sep & 89.8 & 18.7 & 1.85 & 100 \\
\hline
\end{tabular}

magnitude of positive and negative growth rates differed among studies, largely related to food availability and feeding efficiency. The formulation for ingestion of SIMCOs used by Hofmann \& Lascara (2000) resulted in lower ingestion rates than those measured by S. A. Oakes (unpubl. data). At low food concentrations in the experiments, larval krill exhibited higher ingestion rates when feeding by scraping sea ice than when feeding on suspended phytoplankton. This empirically derived functional feeding response yielded enhanced physiological condition in response to low SIMCO chl a concentrations. In the current simulations, an autotrophic diet allowed the assimilation of sufficient carbon for larvae to survive the winter provided that SIMCO biomass was available.

While growth rates in general were similar to historical observations, the model tended to predict higher negative growth in winter and higher positive growth following the SIMCO bloom (Figs. 5 \& 6). Two factors could contribute to the pattern of 
growth in winter: feeding on heterotrophs and high winter respiration rates. Both factors have been observed experimentally and in situ, but the relationship to krill physiological condition is still not well understood. Larval krill in these simulations were able to survive by consuming autotrophs, but heterotrophs may be a significant source of carbon for larval krill in the environment (Meyer et al. 2002, 2009, Schmidt et al. 2006, Töbe et al. 2010). The physiological condition of model krill was sensitive to C:chl a ratio, and the addition of a heterotrophic diet during winter would increase assimilated carbon, which could potentially account for the difference in growth rate.

Respiration rates of simulated krill were similar to measured respiration in summer (Meyer et al. 2003), fall and winter (Meyer et al. 2002, 2009) for the modeled size range. The functional response for respiration in this model was derived from measurements of well-fed krill acclimated at multiple temperatures. This method reproduced some of the seasonal decrease in respiration rate observed in larval krill (17 to $32 \%$ ) but failed to represent the greater than $50 \%$ decrease in respiration observed between fall and winter and between fed and starved larvae (Frazer et al. 2002, Meyer et al. 2002, 2009). The formulation of respiration as a function of wet mass in the model allowed further reduction in total carbon loss related to extreme food limitation yielding negative growth rates. The observation of shrinkage triggering a reduction in respiration is consistent with the switch to protein metabolism observed in starved krill (Frazer et al. 2002), yet this method is not as sensitive to changes in food availability as krill appear to be. It is clear that starved krill exhibit much lower respiration rates than well-fed krill, but the relationship to intermediate food concentrations remains to be defined.

Observations of negative or near zero growth and low carbon assimilation rates in Marguerite Bay in 2001 (Daly 2004, Ross et al. 2004) were consistent with poor physiological condition and survival of model krill in the MB2001 scenario (Table 6. Fig. 6). Interestingly, strong recruitment occurred in the Palmer LTER region in 2001-2002 (Quetin \& Ross 2003), which probably related to extremely high reproductive output overall and good environmental conditions in the Palmer Basin region. Reproductive output in the austral summer of 2000-2001 was high, with average larval densities of 4174 individuals (ind.) $\mathrm{m}^{-2}$ observed near Marguerite Bay in the fall of 2001 (Pakhomov et al. 2004). Assuming survival of $1.85 \%$ of the population in Marguerite Bay (Table 6), larval density in spring would still be approximately 77 ind. $\mathrm{m}^{-2}$. Environmental conditions in Palmer Basin were better for larvae and nearly $90 \%$ of the sample cohort survived the simulation (Table 6).

Variability in the timing of the fall phytoplankton decline and sea ice advance outweighed the effects of the latitudinal gradient in these simulations. High survival in PB2001 resulted from better environmental conditions in the northern region during 2001, whereas conditions promoted higher survival in Marguerite Bay in 2002 (Table 6, Fig. 7). Sea ice advance is later and concentration over the season is more variable farther north along the peninsula (Stammerjohn et al. 2008a,b), whereas sea ice in Marguerite Bay develops earlier and is more likely to overlap or closely follow the fall phytoplankton decline (Stammerjohn et al. 2008a, Vernet et al. 2008). Nevertheless, this north-south contrast in physiological condition and survival indicates that variability along the latitudinal gradient is an important factor in overall recruitment and population dynamics.

Physiological condition of larval krill was sensitive to parameters that determined carbon availability and assimilation: the rate of phytoplankton decline, DVM, $A E$ and SIMCO biomass. The higher than expected simulated survival rates probably relate to an over-estimated feeding time budget and availability of food in the sea ice. Unfortunately, little empirical information is available for many of these conditions. The seasonal pattern of DVM was developed with limited observations of larval behavior under the sea ice, assumptions on the role of light and comparisons of test simulations to historical observations of growth. Interestingly, DVM was necessary to reproduce measured ingestion and growth rates. Larvae associated with the sea ice for a longer time period than $f$ (Table 2) exhibited unrealistically high ingestion rates, growth rates and $C F$, while larvae that never associated with sea ice in winter starved. The behavioral response to light was used to constrain carbon assimilation; however, the required limitation of carbon intake could come from an endogenous physiological response to the decreased light during winter.

Chl a available in SIMCOs was modeled for the bottom $5 \mathrm{~cm}$ of sea ice, all of which may not be available to grazing larvae. Larval krill have difficulty feeding by filtration and scraping at high food concentrations (Oakes 2008), and may become satiated or form boluses that obstruct feeding at chl a concentrations as high as $43 \mathrm{mg} \mathrm{m}^{-3}$ (Fig. 2). $A E$ is also an important factor affecting the carbon budget during fall and winter. Oakes (2008) and Meyer et 
al. (2003) found $A E$ was not significantly correlated to food concentration, but was highly variable within experimental treatments. The drivers of variability in $A E$ are not well understood for larval krill. It is conceivable that $A E$ could decrease when food availability reaches concentrations modeled in the sea ice, which reduces carbon assimilation and potentially constrains growth rates during the SIMCO bloom. This study identified multiple areas in which empirical information is needed: functional response of physiological rates (respiration and assimilation efficiency) to variable food quality and concentration, as well as larval condition, composition and utilization of the ice-associated heterotrophic community and light-driven behavioral and physiological responses in larval krill.

\section{Effects of environmental variability during fall and winter}

In the present simulations, the timing and magnitude of food availability were major factors controlling growth rate and $C F$ of larval krill in Marguerite Bay and Palmer Basin, western Antarctic Peninsula. Timing, in this sense, refers to when a food source becomes available and the duration of availability to larval krill. Magnitude refers to the amount of food available in terms of modeled chl $a$ in the water column and sea ice. The model results identified 3 important environmental processes that drive food availability and, consequently, the physiological condition of larvae throughout this critical period: the rate of the fall phytoplankton decline, timing of development of sea ice and SIMCOs in early winter and the SIMCO bloom in late winter.

The rate of the phytoplankton decline determined the duration of positive growth and carbon accumulation in fall, as well as when larval krill were required to utilize stored energy reserves to meet respiratory demands. The phytoplankton decline was, therefore, the major factor in controlling physiological condition during the winter. This was an unexpected result, as no previous studies have linked fall phytoplankton dynamics to larval survival and recruitment.

Carbon accumulation in larval krill is a function of the integrated exposure (duration and magnitude) to a food source. If the decline of phytoplankton biomass is slow, larvae experience greater exposure to food and exhibit higher $C F$ and positive growth later in the winter (PB2001, MB2001 and MB2002). In contrast, a rapid decline of fall phytoplankton biomass results in less exposure to food, lower $C F$ and early negative growth rates (PB2002). Negative $\Delta C_{\mathrm{b}}$ and the loss of $50 \%$ of $C_{\max }$ occurred nearly 1 mo earlier in PB2002 than in PB2001 (Table 4). As a result, larvae could not meet respiratory requirements during winter and were required to utilize carbon from both energy reserves and structural body components early in the winter, which led to significant starvation-related mortality before August (Table 6).

During the SO GLOBEC cruises, Daly (2004) and Pakhomov et al. (2004) observed high mortality of early larval stages of krill in fall and winter, leading to the late larval stages, FIV to FVI, representing the largest proportion of larval krill by the end of winter. Survival experiments conducted at Palmer Station in winter also indicated survival time was longer for larger, more developed larvae (summarized in Ross \& Quetin 1991). The current simulations showed that conditions promoting growth and carbon accumulation in fall led to greater tolerance to food limitation later in the season (Lowe 2010). Only larvae entering the fall with high $C F$ and greater initial length survived scenarios with high starvation-related mortality (Fig. 7b,c). This result presents further evidence that the availability of food in fall, through continued growth and carbon accumulation, is a critical factor in the survival of larvae through winter. It is important to note that Palmer Basin and Marguerite Bay typically exhibit higher fall chl a concentrations than do other recognized 'nursery' regions (Pakhomov et al. 2004, Marrari et al. 2008, Schmidt et al. 2012). It is conceivable that the decline of phytoplankton biomass during fall would be of greater importance to larval krill in regions of lower annual production.

The second important process controlling food available to larval krill was the advance of seasonal sea ice and SIMCO development. Timing of sea ice advance has been identified as an important factor driving recruitment success along the WAP (Siegel \& Loeb 1995, Quetin \& Ross 2003, Quetin et al. 2007). The hypothesized importance of sea ice advance to larval krill physiological condition is supported by these findings; however, the results suggest that the timing of sea ice advance is most important in relation to the fall phytoplankton decline. The early advance of sea ice reduces the likelihood of food limitation during the period of extremely low food availability in the water column after the fall phytoplankton decline.

The importance of early sea ice advance is a function of the interplay among fall phytoplankton dynamics, phytoplankton scavenging and in situ produc- 
tion in the sea ice. The time-integrated exposure to photosynthetically active radiation (TIEP) is much greater for early forming sea ice, and thus provides more energy for SIMCO production (Fritsen et al. 2011). Owing to early sea ice formation, measured TIEP was 10-fold higher in 2002 than in 2001 and corresponded to significantly higher chl a concentrations (Fritsen et al. 2011). The combined effect of early formation and in situ production of sea ice is a greater abundance of SIMCO biomass that is available to larval krill during the period of minimum or absence of light in winter. In 3 of the scenarios (PB2001, MB2001 and MB2002), $\Delta C_{\mathrm{b}}$ became negative at approximately the same date and occurred before the availability of SIMCOs (Table 4). However, larvae differed greatly in the rate of carbon loss subsequent to $\Delta C_{\mathrm{b}}$ becoming negative (Figs. $5 \& 6$, reflected in growth rate and $C F$ ). Sea ice advance and availability of SIMCO biomass occurred earlier in MB2002 than in PB2001 and MB2001 by 28 and $44 \mathrm{~d}$, respectively (Stammerjohn et al. 2008a). As a result, the period between negative $\Delta C_{\mathrm{b}}$ and loss of $50 \%$ of $C_{\max }$ was $107 \mathrm{~d}$ in MB2002 compared with a period of $66 \mathrm{~d}$ in PB2001 and $63 \mathrm{~d}$ in MB2001 (Table 4). The early availability of SIMCOs in MB2002 slowed the rate of carbon loss by subsidizing the utilization of stored carbon to meet respiratory demands.

The third environmental process determining larval physiological condition and survival was the late winter SIMCO bloom. Availability of increased SIMCO biomass arrested the seasonal decline in growth rate and $C F$ (Figs. $5 \& 6$ ) and led to a decrease in mortality due to starvation (Table 6). In contrast, the lack of a SIMCO bloom in MB2001 resulted in a continued decrease in physiological condition and survival until the end of the simulation (Fig. 6, Table 6). The importance of late winter sea ice dynamics for individual larval krill suggested by these results is supported by investigations of overall patterns of recruitment along the wAP (Siegel \& Loeb 1995). In the Palmer LTER region, larval krill recruitment was positively correlated to the ratio of August sea ice area to extent (Quetin \& Ross 2003, Wiedenmann et al. 2009). A higher area to extent ratio implies there is more developed pack ice that provides a stable environment for SIMCO production. Larval krill have been observed to associate with over-rafted and complex sea ice habitat that may only be available in well-developed sea ice (Ross et al. 2004, Meyer et al. 2009). Thinner ice pack, periodic break-up or ice floe movement could result in less primary production in the sea ice and the separation of larvae from this important late winter food source.

The results of manipulated environmental conditions simulations support the finding that fall phytoplankton dynamics are the main control of largescale patterns of physiological condition of krill throughout the critical period of fall and winter. A slow phytoplankton decline resulted in larvae maintaining $C F$ above $C_{0.35}$ in all cases, whereas a rapid phytoplankton decline led to $C F$ decreasing to $C F_{0.35}$ before the end of winter regardless of SIMCO dynamics. However, the timing of sea ice advance and development of SIMCOs did affect the rate of carbon loss and $C F$ decrease later in winter. An early sea ice advance slowed the decrease in $C F$, whereas late sea ice advance led to a rapid decrease to $C F_{0.35}$ and a lower minimum $C F$. This experiment also highlighted the importance of the late winter SIMCO bloom in that growth rate and $C F$ recovered after a SIMCO bloom but continued to decrease if no bloom occurred.

Over the last 3 decades, total summer primary production in the northern wAP decreased (MontesHugo et al. 2009) and sea ice advanced 1 to 4 d later and retreated 1 to $2 \mathrm{~d}$ earlier per year along the wAP (Stammerjohn et al. 2008b). Marrari et al. (2008) showed krill recruitment indices are positively correlated to spring and summer chl a concentrations and suggested the persistence of seasonal phytoplankton biomass is important for recruitment. While summer phytoplankton biomass is not necessarily a strong indicator of fall phytoplankton dynamics (Vernet et al. 2012), persistent phytoplankton availability was crucial to larval krill growth and survival in the present study. The decreased summer primary production observed by Montes-Hugo et al. (2009) could reduce food availability to developing larvae in late summer, thereby reducing their tolerance to food limitation and making them more susceptible to starvation in the event of delayed ice advance and SIMCO availability (Lowe 2010). In addition to changing primary production and sea ice dynamics, surface water temperature along the wAP is increasing (Meredith \& King 2005). Rising water temperature will increase respiration rate (Fig. 3) resulting in a greater carbon requirement. In the context of the model results, the cumulative effect of decreasing primary productivity, shorter ice season and increased water temperature is reduced physiological condition of larval krill, which potentially translates to reduced recruitment and an overall decline in krill abundance as observed in the SW Atlantic sector by Atkinson et al. (2004). 


\section{CONCLUSIONS}

The results of this study offer insight into the relationship between sea ice dynamics and observed recruitment indices by describing the physiological condition and survival of larval krill in response to phytoplankton and sea ice variability during fall and winter. The model represents a framework that could incorporate empirical data regarding larval physiological rates in a greater range of conditions and geographical locations to investigate future larval krill dynamics in relation to the changing Southern Ocean ecosystem.

Incorporation of empirically derived, temperaturedependent physiological rates and behavioral effects on ingestion resulted in a realistic representation of the growth and $C F$ of larval Antarctic krill in fall and winter. The model accurately simulated seasonal fluctuations of growth and energy reserves by modeling $L$ and $C F$ as separate carbon pools determined by the balance of carbon gains and losses. Model results also highlight the importance of light-driven behavior to larval krill physiological dynamics in fall and winter. During winter, larvae fed efficiently on SIMCOs in low concentrations and respiration rates decreased in response to lower surface water temperature. As a result, larvae along the wAP were able to survive on a diet composed of autotrophs in the water column and sea ice.

The interplay between physiological processes that determine tolerance to food limitation and environmental processes that drive food availability is a key factor for larval krill survival during fall and winter. Results of this study support the hypothesis that sea ice advance and development of SIMCOs are important to the survival of larval Antarctic krill, but also identify the decline of phytoplankton biomass in fall and the SIMCO bloom in late winter as significant factors that determine the physiological condition of larval krill. Larval krill were found to be particularly sensitive to food availability in fall in the study regions. Consequently, the results suggest fall phytoplankton dynamics have a greater effect on the overall physiological condition of larvae during this critical period than previously recognized.

Acknowledgements. Funding for this work was provided by the National Science Foundation Office of Polar Programs through projects ANT-0529087, ANT-0529666 and ANT0528728 in the Collaborative Research: United States Southern Ocean Global Ocean Ecosystems Dynamics Synthesis and Modeling program. Larval ingestion experiments and analysis were supported under award numbers DPP-
8518872 and ANT-0529087. Sample collection and analysis of condition factor and total length and weight measurements were supported under award numbers DPP-8518872, DPP-8820589 and OPP-9117633 (for the WinCruises and Mar-Apr 1988) and award number OPP-9909933 for the SO GLOBEC cruises. Additional sample collection was supported by award numbers OPP-9011927, OPP-9632763 (for $C F$ from the LTER cruises) and OPP-9117633 (for respiration). Retrieval and analysis of historical data were supported by award number ANT-0529087 and by the Regents of the University of California and the University of California at Santa Barbara. This work formed part of A.T.L.'s Master's thesis, and feedback from R. Nisbet and A. Alldredge was greatly appreciated during model development and the writing process. Comments from the anonymous reviewers also greatly improved the manuscript. We extend special thanks to the US Antarctic Program, the crews of the RV 'Lawrence M. Gould' and RVIB 'Nathanial B. Palmer' and the scientific support staff at Palmer Station.

\section{LITERATURE CITED}

Ackley SF, Sullivan CW (1994) Physical controls on the development and characteristics of Antarctic sea ice biological communities - a review and synthesis. Deep-Sea Res I 41:1583-1604

Atkinson A, Siegel V, Pakhomov E, Rothery P (2004) Longterm decline in krill stock and increase in salps within the Southern Ocean. Nature 432:100-103

Comiso J (1999, updated 2008) Bootstrap sea ice concentrations from NIMBUS-7 SMMR and SMSP SSM/I, 01 March 1979 to 31 December 2007. National Snow and Ice Data Center, Boulder, CO (digital media)

$>$ Daly KL (1990) Overwintering development, growth, and feeding of larval Euphausia superba in the Antarctic marginal ice zone. Limnol Oceanogr 35:1564-1576

> Daly KL (2004) Overwintering growth and development of larval Euphausia superba: an interannual comparison under varying environmental conditions west of the Antarctic Peninsula. Deep-Sea Res II 51:2139-2168

> Daly KL, Macaulay MC (1991) Influence of physical and biological mesoscale dynamics on the seasonal distribution and behavior of Euphausia superba in the Antarctic marginal ice zone. Mar Ecol Prog Ser 79:37-66

Everson I (2000) The Southern Ocean food web. In: Everson I (ed) Krill: biology, ecology and fisheries. Blackwell Science, Oxford, p 182-227

Fach BA, Meyer B, Wolf-Gladrow D, Bathmann U (2008) Biochemically based modeling study of Antarctic krill Euphausia superba growth and development. Mar Ecol Prog Ser 360:147-161

Fraser FC (1936) On the development and distribution of the young stages of krill (Euphausia superba). Discov Rep 14:1-192

> Frazer TK, Quetin LB, Ross RM (2002) Energetic demands of larval krill, Euphausia superba, in winter. J Exp Mar Biol Ecol 277:157-171

Fritsen CH, Kremer JN, Ackley SF, Sullivan CW (1998) Flood-freeze cycles and algal dynamics in Antarctic pack ice. In: Lizotte ML, Arrigo KR (eds) Antarctic sea ice: biological processes. Am Geophys Union (Antarct Res Ser) 73:1-21

Fritsen CH, Memmott J, Stewart FJ (2008) Inter-annual sea-ice dynamics and micro-algal biomass in winter pack 
ice of Marguerite Bay, Antarctica. Deep-Sea Res II 55: 2059-2067

Fritsen CH, Memmott JC, Ross RM, Quetin LB, Vernet M, Wirthlin E (2011) The timing of sea ice formation and exposure to photosynthetically active radiation along the Western Antarctic Peninsula. Polar Biol 34:683-692

Garrison DL, Ackley SF, Buck KR (1983) A physical mechanism for establishing algal populations in frazil ice. Nature 306:363-365

> Garrison DL, Close AR, Reimnitz E (1989) Algae concentrated by frazil ice: evidence from laboratory experiments and field measurements. Antarct Sci 1:313-316

> Hofmann EE, Lascara CM (2000) Modeling the growth dynamics of Antarctic krill Euphausia superba. Mar Ecol Prog Ser 194:219-231

Ikeda T, Bruce B (1986) Metabolic activity and elemental composition of krill and other zooplankton from Prydz Bay, Antarctica, during early summer (NovemberDecember). Mar Biol 92:545-555

> Ikeda T, Dixon P (1982) Body shrinkage as a possible overwintering mechanism of Antarctic krill, Euphausia superba Dana. J Exp Mar Biol Ecol 62:143-151

Laws RM (1985) The ecology of the Southern Ocean. Am Sci 73:26-40

Lowe AT (2010) Simulating growth and condition factor of larval Antarctic krill in response to environmental variability during fall and winter with an individual-based model. MS thesis, University of California Santa Barbara

Marin V, Huntley ME, Frost B (1986) Measuring feeding rates of pelagic herbivores: analysis of experimental design and methods. Mar Biol 93:49-58

Marrari M, Daly K, Hu C (2008) Spatial and temporal variability of SeaWiFS chlorophyll a distributions west of the Antarctic Peninsula: implications for krill production. Deep-Sea Res II 55:377-392

Meredith MP, King JC (2005) Rapid climate change in the ocean west of the Antarctic Peninsula during the second half of the 20th Century. Geophys Res Lett 32:L19604. doi:10.1029/2005GL024042

Meyer B, Oettl B (2005) Effects of short-term starvation on composition and metabolism of larval Antarctic krill Euphausia superba. Mar Ecol Prog Ser 292:263-270

> Meyer B, Atkinson A, Stübing D, Oettl B, Hagen W, Bathmann UV (2002) Feeding and energy budgets of Antarctic krill Euphausia superba at the onset of winter - Furcilia III larvae. Limnol Oceanogr 47:943-952

Meyer B, Atkinson A, Blume B, Bathmann UV (2003) Feeding and energy budgets of larval Antarctic krill Euphausia superba in summer. Mar Ecol Prog Ser 257:167-177

Meyer B, Fuentes V, Guerra C, Schmidt K and others (2009) Physiology, growth, and development of larval krill Euphausia superba in autumn and winter in the Lazarev Sea, Antarctica. Limnol Oceanogr 54:1595-1614

Montes-Hugo M, Doney SC, Ducklow HW, Fraser W, Martinson D, Stammerjohn SE, Schofield O (2009) Recent changes in phytoplankton communities associated with rapid regional climate change along the Western Antarctic Peninsula. Science 323:1470-1473

Nast F (1978) The vertical distribution of larval and adult krill (Euphausia superba Dana) on a time station south of Elephant Island, South Shetlands. Meeresforsch 27: 103-118

Oakes SA (2008) Winter ecology of young Antarctic krill, Euphausia superba: feeding on the sea ice microbial community with implications for growth models. PhD dissertation, University of California Santa Barbara, CA Pakhomov EA, Atkinson A, Meyer B, Oettl B, Bathmann U (2004) Daily rations and growth of larval krill Euphausia superba in the Eastern Bellingshausen Sea during austral autumn. Deep-Sea Res II 51:2185-2198

Quetin LB, Ross RM (1989) Effects of oxygen, temperature and age on the metabolic rate of the embryos and early larval stages of the Antarctic krill Euphausia superba Dana. J Exp Mar Biol Ecol 125:43-62

> Quetin LB, Ross RM (2003) Episodic recruitment in Antarctic krill Euphausia superba in the Palmer LTER study region. Mar Ecol Prog Ser 259:185-200

> Quetin LB, Ross RM, Frazer TK, Amsler MO, Wyatt-Evans C, Oakes SA (2003) Growth of larval krill, Euphausia superba, in fall and winter west of the Antarctic Peninsula. Mar Biol 143:833-843

Quetin LB, Ross RM, Fritsen CH, Vernet M (2007) Ecological responses of Antarctic krill to environmental variability: Can we predict the future? Antarct Sci 19:253-266

Ross RM, Quetin LB (1991) Ecology and physiology of larval euphausiids, Euphausia superba (Euphausiacea). Mem Queensl Mus 31:321-333

> Ross RM, Quetin LB, Kirsch E (1988) Effect of temperature on developmental times and survival of early larval stages of Euphausia superba Dana. J Exp Mar Biol Ecol 121:55-71

> Ross RM, Quetin LB, Baker KS, Vernet M, Smith RC (2000) Growth limitation in young Euphausia superba under field conditions. Limnol Oceanogr 45:31-43

Ross RM, Quetin LB, Newberger T, Oakes SA (2004) Growth and behavior of larval krill (Euphausia superba) under the ice in late winter 2001 west of the Antarctic Peninsula. Deep-Sea Res II 51:2169-2184

Schmidt K, Atkinson A, Petzke KJ, Voss M, Pond D (2006) Protozoans as a food source for Antarctic krill, Euphausia superba: complementary insights from stomach content, fatty acids, and stable isotopes. Limnol Oceanogr 51: 2409-2427

Schmidt K, Atkinson A, Venables HJ, Pond DW (2012) Early spawning of Antarctic krill in the Scotia Sea is fuelled by 'superfluous' feeding on non-ice associated phytoplankton blooms. Deep-Sea Res II 59:159-172

Siegel V (2005) Distribution and population dynamics of Euphausia superba: summary of recent findings. Polar Biol 29:1-22

> Siegel V, Loeb V (1995) Recruitment of Antarctic krill Euphausia superba and possible causes for its variability. Mar Ecol Prog Ser 123:45-56

Stammerjohn SE, Martinson DG, Smith RC, Iannuzzi RA (2008a) Sea ice in the western Antarctic Peninsula region: spatio-temporal variability from ecological and climate change perspectives. Deep-Sea Res II 55:2041-2058

> Stammerjohn SE, Martinson DG, Smith RC, Yuan X, Rind D (2008b) Trends in Antarctic annual sea ice retreat and advance and their relation to El Niño-Southern Oscillation and Southern Annular Mode variability. J Geophys Res 113:C03S90. doi:10.1029/2007JC004269

> Stretch JJ, Hamner PP, Hamner WM, Michel WC, Cook J, Sullivan CW (1988) Foraging behavior of Antarctic krill Euphausia superba on sea ice microalgae. Mar Ecol Prog Ser 44:131-139

Töbe K, Meyer B, Fuentes V (2010) Detection of zooplankton items in the stomachs of larval krill, Euphausia superba, using a molecular approach. Polar Biol 33:407-414

Vernet M, Martinson DG, Iannuzzi RA, Stammerjohn SE 
and others (2008) Primary production within the sea-ice zone west of the Antarctic Peninsula: I-Sea-ice, summer mixed layer, and irradiance. Deep Sea Res II 55: 2068-2085

> Vernet M, Kozlowski WA, Yarmey LR, Lowe AT, Ross RM, Quetin LB, Fritsen CH (2012) Primary production

Editorial responsibility: Hans Heinrich Janssen, Oldendorf/Luhe, Germany throughout austral fall, during a time of decreasing daylength in the western Antarctic Peninsula. Mar Ecol Prog Ser 452:45-61

> Wiedenmann J, Cresswell K, Mangel M (2009) Connecting recruitment of Antarctic krill and sea ice. Limnol Oceanogr 54:799-811

Submitted: March 30, 2011; Accepted: September 21, 2011 Proofs received from author(s): April 9, 2012 